\title{
Influence of urbanisation on physical activity and dietary changes in Huli-speaking population: a comparative study of village dwellers and migrants in urban settlements
}

\author{
Taro Yamauchi*, Masahiro Umezaki and Ryutaro Ohtsuka \\ Department of Human Ecology, School of International Health, Graduate School of Medical Sciences, University of Tokyo, \\ Tokyo, Japan \\ (Received 10 January 2000 - Revised 21 June 2000 - Accepted 17 July 2000)
}

\begin{abstract}
The influence of urbanisation on physical activity and dietary changes was examined in a Papua New Guinea Highland population. Adult male and female subjects ( $n$ 56) were selected, including twenty-seven rural villagers and twenty-nine urban migrants. BMR was calculated from values measured in similar samples of Huli-speaking population, according to gender and body weight. Total daily energy expenditure (TEE) was assessed by $24 \mathrm{~h}$ heart rate (HR) monitoring (flex-HR method) and physical activity level (PAL) calculation was based on BMR. Energy, protein and fat intakes were measured by weighing food on a single day. Urban subjects were heavier and taller than their rural counterparts; significant differences were found in stature in men $(P<0.05)$ and body weight in women $(P<0.05)$. Urban subjects had longer sedentary periods $(\mathrm{HR} \leq$ flex-HR) and shorter active periods (HR $>$ flex-HR) than rural subjects. Consequently, the former had lower TEE and PAL than the latter; significant differences were found in women (TEE, $P<0.05$, PAL, $P<0.01$ ) but not in men. Total daily energy intake and TEE were well balanced $(<7 \%)$ in all groups, whereas protein and fat intakes were considerably higher in urban subjects than rural subjects. Reduced PAL and increased fat intake by urban dwellers may increase the risks of obesity and chronic degenerative diseases.
\end{abstract}

Physical activity: Energy balance: Urbanisation

Non-communicable diseases such as obesity, diabetes and cardiovascular disorders have long been the main health problems in developed countries, while in recent decades the prevalence of these diseases and their antecedent risk factors have rapidly increased in developing countries, known as 'health transition' (Sinnett et al. 1992; Taylor et al. 1992; Hodge et al. 1996). These changes are caused to a large extent by Westernised dietary changes and a reduction in daily physical activity in relation to socioeconomic and living environmental conditions (King \& Collins, 1989; Dowse et al. 1994; Hodge et al. 1995).

Although a large number of studies have evaluated the dietary changes in various urban populations in developing countries, little is known about the physical activity levels (PAL) in these populations (Stein et al. 1988; Spurr et al. 1996). This situation is mainly due to the difficulties in measuring energy expenditure (EE), particularly total daily energy expenditure (TEE), in free-living situations (World Health Organization/Food and Agriculture Organization/
United Nations University (FAO/WHO/UNU), 1985; Durnin, 1990). In fact, there are only a few studies that have quantitatively compared the patterns of physical activity between urban and rural dwellers who shared the same genetic traits and cultural background (often seen in rural-urban migrants and rural residents of the same group). Such comparisons are useful for determining the effect of urbanisation.

The subjects of this study were Huli-speaking villagers in their homeland in Papua New Guinea (PNG) Highlands and their migrants who lived in settlements (i.e. spontaneously developed residential areas) in Port Moresby, the national capital city of PNG; field work was conducted from July to September in 1994 for the former and from July to September in 1995 for the latter. We monitored the heart rate $(\mathrm{HR})$ and measured the amounts of all foods consumed among adult samples of the two groups. The aims of the study were: (1) comparison of nutritional status (body weight and BMI) between rural villagers and urban

\footnotetext{
Abbreviations: EE, energy expenditure; HR, heart rate; PAL, physical activity level; PNG, Papua New Guinea; TEE, total daily energy expenditure; TEI, total daily energy intake; WHO/FAO/UNU, World Health Organization/Food and Agriculture Organization/United Nations University. * Corresponding author: Dr T. Yamauchi, fax +8135841 3395, email taro@humeco.m.u-tokyo.ac.jp
} 
migrants; (2) comparison of daily PAL between the two groups, with special interest in possible reduction of physical activity in the migrant group; (3) comparison of energy and major nutrient (protein and fat) intakes between the two groups, with special emphasis on dietary changes by urbanisation.

\section{Subjects and methods}

\section{Study populations}

The Huli, one of the largest language groups in PNG, have inhabited the Tari basin located $1600 \mathrm{~m}$ above sea level between $142^{\circ} 70^{\prime}$ and $143^{\circ} 30^{\prime}$ east longitude and between $5^{\circ} 70^{\prime}$ and $6^{\circ} 20^{\prime}$ south latitude in the central part of Southern Highlands Province, PNG. They have subsisted on agriculture of sweet potatoes (Ipomoea batatas) and pig husbandry (Kuchikura, 1999; Umezaki et al. 1999; Yamauchi et al. 2000). Most migration of the Highlanders, including the Huli, to Port Moresby has progressively increased since the 1970s, particularly since the time of independence of PNG in 1975. Migrants from rural villages reside in settlements in Port Moresby by ethnic groups. The houses are built by the migrants themselves using secondhand or makeshift materials. Most of the migrants have not been able to obtain jobs in the formal sector, and thus have depended for their livelihood on income from informal sector jobs such as collection of empty bottles and selling of betel-nuts (nuts of Areca cateichu), cigarettes and/or cooked meat in markets or settlements. The major socioeconomic differences between the Huli rural and urban groups can be summarised as follows: (1) change in occupational activities from subsistence agriculture in rural villages to cash-earning work in urban settlements; (2) change in dietary pattern, represented by changes in staple foods from sweet potato and leafy greens in the former to purchased foods such as rice, tinned fish and lamb chops in the latter.

\section{Subjects}

Married men and women, fifty-six in total, volunteered to participate in the present study. They included twentyseven villagers (fifteen men and twelve women) from two villages, and twenty-nine urban dwellers (fourteen men and fifteen women) from three settlements in Port Moresby. The rural subjects represented almost the entire adult populations of these two areas during the study period. The urban subjects were selected to match the age distribution of their village counterparts. All urban subjects were born and grew up in their homeland in the Tari basin. The average length of living in Port Moresby was 15 (range 0$35)$ years for men and $7 \cdot 1(1-20)$ years for women. In addition, the average ages of these individuals when they migrated to Port Moresby were 21.6 and 26.4 years for men and women respectively. Elderly subjects over 60 years and pregnant women were not sampled due to the difficulty of conducting the step test (see p. 66). Ten lactating women (four in the rural sample and six in the urban sample) were included in the present study; there were no problems in collecting data from them and so their records were analysed without any special treatment. One of the authors (T.Y.) explained the purpose of the investigation to the participants in Tok Pisin (pidgin English, the lingua franca in PNG), with occasional assistance of interpreters.

\section{Anthropometry}

Before breakfast in the early morning, the body weight of each subject was measured using a portable scale with a precision of $\pm 0.1 \mathrm{~kg}$. Stature was measured to the nearest $1 \mathrm{~mm}$ using a portable field anthropometer (GPM, Switzerland). For rural samples, stature data were collected from twenty subjects (eleven men and nine women) who participated in the food consumption survey conducted in January 1995. Unfortunately, height was not measured in the remaining seven subjects in the HR monitoring survey conducted between July and September 1994. Their stature, however, was on average not markedly different from that of the other twenty rural subjects.

\section{Heart rate monitoring}

Using a cardio-frequency meter (Vantage XL; Polor Electro, Kempele, Finland), HR of each subject was monitored for $24 \mathrm{~h}$ from about 18.00 hours to the same time on the following day for most subjects, or from early morning (from 06.00 to 08.00 hours) to the same time on the following morning for some urban subjects. The HR monitoring system consisted of an electrode-belt transmitter and a wrist microcomputer receiver, which digitised and stored the recorded pulse. This system was light $(<100 \mathrm{~g})$ and did not disturb the subject's behaviour. The pulse was recorded at $1 \mathrm{~min}$ intervals and the maximum recording capacity of the system was $2020 \mathrm{~min}$. Some HR profiles were excluded from analysis due to faulty electrode contact. Subsequent analysis of the HR and behavioural data indicated that transmission problems, recognised as zero or spikes, occurred during both rest and exercise and were not specific to given activities (Panter-Brick et al. 1996; Yamauchi et al. 2000). The recordings in these short gaps were replaced with the average HR calculated from the data on either side of the gap (Leonard et al. 1995; Yamauchi et al. 2000).

\section{Step test}

On the day of investigation each subject was requested to do two different step tests (stepping-1 and stepping-2) following the author's instructions in Tok Pisin or Huli language. The duration of each step test was $3 \mathrm{~min}$ and the height of the step was $0 \cdot 3 \mathrm{~m}$. In stepping- 1 and stepping-2 tests each subject stepped up and down at a constant pace of fifteen and thirty steps per min respectively. A metronome was used to achieve a steady-state condition for stepping exercises. The HR value in the final minute was used for analysis.

\section{$B M R$, resting metabolic rate and energy cost of step test}

BMR and EE at rest (lying, sitting and standing) and during step tests were determined based on the subject's body 
weight, gender and the energy costs, which were measured in Huli-speaking individuals using the Douglas bag technique of indirect calorimetry (Douglas, 1911) on other occasions; the gender- and weight-specific BMR values used for estimation were 77.8 and $70.8 \mathrm{~J} / \mathrm{kg}$ per min for rural $(n 9)$ and urban $(n 9)$ men respectively, and 75.8 and $66.5 \mathrm{~J} / \mathrm{kg}$ per min for rural $(n 7)$ and urban $(n 8)$ women respectively (Yamauchi \& Ohtsuka, 2000). Resting metabolic rates were determined as the mean of energy costs measured when lying, sitting and standing (Katzmarzyk et al. 1994; Leonard et al. 1995; Murayama \& Ohtsuka, 1999).

\section{Determination of flex-heart rate points and estimation of total energy expenditure}

There is no standard procedure for determination of the flex-HR point which discriminates between resting and exercise HR values (Panter-Brick et al. 1996). In the present study, we used the method described previously by our laboratory (Yamauchi et al. 2000). Flex-HR was determined as the mean of the mean HR of the three resting activities (lying, sitting and standing) and the lowest HR during stepping exercise (i.e. stepping-1). The recorded HR values were then converted to energetic equivalents using each subject's EE $v$. HR regression line.

TEE was estimated by the flex-HR method (Spurr et al. 1988; Ceesay et al. 1989) and EE during sleeping was assumed to equal BMR (Goldberg et al. 1988). For HR values which were equal to and below the flex-HR point (i.e. 'sedentary' HR), the RMR determined as the mean EE values for lying, sitting and standing was assumed to represent their energy costs. Values above the flex-HR point ('active' HR) were converted to energy costs based on a regression line which was calibrated for each subject. The TEE was then calculated using the following formula:

$$
\begin{aligned}
\mathrm{TEE}= & \Sigma(\text { sleeping EE })+\Sigma(\text { sedentary EE }) \\
& +\Sigma(\text { active EE }) .
\end{aligned}
$$

PAL (TEE/BMR; James et al. 1988) was also determined. The use of PAL allows comparison of individuals of different body size. PAL values are a universally accepted way of expressing EE and they help to convey an easily understandable concept (Ferro-Luzzi \& Martino, 1996).

\section{Dietary intake}

Dietary consumption was studied for each subject on the same day as HR monitoring. All foods consumed were weighed with a portable beam scale or a spring scale before cooking throughout the daytime period. In addition, the subjects were asked in the morning about the types and amounts of foods consumed during the previous night. Sweet potatoes and green leaves, which were most frequently eaten in the villages, were sampled in the Huli villages and their food compositions were determined in the laboratory in Japan. For other foodstuffs, the energy and major nutrient contents were estimated using food composition tables of Hongo \& Ohtsuka (1993) and other available data for PNG and the surrounding areas (Umezaki et al. 1999).

\section{Statistical analysis}

Data were expressed as means and standard deviations. Differences between groups were examined for statistical significance using the unpaired $t$ test. $P<0.05$ was considered significant.

\section{Results}

Table 1 shows the number of subjects listed by age-group and their physical characteristics. Since rural subjects did not know their exact age, they were categorised into three groups (20-30, 30-40 and $>40$ years) according to the census data of the PNG Institute of Medical Research (Tari branch) and the authors' interviews. Urban women, but not men, were significantly heavier than their rural counterparts $(P<0.05)$, while urban men were significantly taller than their rural counterparts $(P<0 \cdot 05)$.

BMR, TEE, PAL and the level of work classified according to PAL (WHO/FAO/UNU, 1985) are presented in Table 2. No significant difference was found in BMR in

Table 1. Age distribution and physical characteristics of the Papua New Guinea Highland subjects participating in the study

\begin{tabular}{|c|c|c|c|c|c|c|c|c|}
\hline \multirow[b]{2}{*}{ Age-group (years) } & \multicolumn{4}{|c|}{ Men } & \multicolumn{4}{|c|}{ Women } \\
\hline & \multicolumn{2}{|c|}{ Rural (n 15) } & \multicolumn{2}{|c|}{ Urban (n 14) } & \multicolumn{2}{|c|}{ Rural (n 12) } & \multicolumn{2}{|c|}{ Urban (n 15) } \\
\hline $\begin{array}{l}20-30 \\
30-40 \\
>40\end{array}$ & \multicolumn{2}{|c|}{$\begin{array}{l}5(33) \dagger \\
7(47) \\
3(20)\end{array}$} & \multicolumn{2}{|c|}{$\begin{array}{l}3(21) \dagger \\
7(50) \\
4(29)\end{array}$} & \multicolumn{2}{|c|}{$\begin{array}{l}3(25) \dagger \\
5(42) \\
4(33)\end{array}$} & \multicolumn{2}{|c|}{$\begin{array}{l}7(47) \dagger \\
6(40) \\
2(13)\end{array}$} \\
\hline & Mean & SD & Mean & SD & Mean & $\mathrm{SD}$ & Mean & SD \\
\hline $\begin{array}{l}\text { Age (years) } \\
\text { Weight }(\mathrm{kg}) \\
\text { Height }(\mathrm{m}) \ddagger \\
\text { BMI }\left(\mathrm{kg} / \mathrm{m}^{2}\right) \ddagger\end{array}$ & $\begin{array}{c}63 \cdot 6 \\
1.58 \\
24.8\end{array}$ & $\begin{array}{l}7.3 \\
0.03 \\
1.6\end{array}$ & $\begin{array}{l}36 \cdot 1 \\
70 \\
1 \cdot 63^{*} \\
26 \cdot 4\end{array}$ & $\begin{array}{l}10.0 \\
9.5 \\
0.05 \\
3.3\end{array}$ & $\begin{array}{c}53.3 \\
1.50 \\
23.2\end{array}$ & $\begin{array}{l}7.6 \\
0.05 \\
3.0\end{array}$ & $\begin{array}{c}31 \cdot 4 \\
59 \cdot 7^{\star} \\
1.53 \\
25.5\end{array}$ & $\begin{array}{l}8 \cdot 2 \\
6 \cdot 4 \\
0.05 \\
3 \cdot 1\end{array}$ \\
\hline
\end{tabular}
(Mean values and standard deviations)

NA, not available.

Mean values were significantly different from those of rural subjects: ${ }^{\star} P<0.05$.

$\dagger$ Values in parentheses are the percentage of the total number of subjects for each group.

$\ddagger$ Mean values for eleven rural men and nine rural women. 
Table 2. BMR, total daily energy expenditure (TEE), physical activity level (PAL) and work level of men and women in rural and urban populations of Papua New Guinea†

(Mean values and standard deviations)

\begin{tabular}{|c|c|c|c|c|c|c|c|c|}
\hline & \multicolumn{4}{|c|}{ Men } & \multicolumn{4}{|c|}{ Women } \\
\hline & \multicolumn{2}{|c|}{ Rural (n 15) } & \multicolumn{2}{|c|}{ Urban (n 14) } & \multicolumn{2}{|c|}{ Rural (n 12) } & \multicolumn{2}{|c|}{ Urban (n 15) } \\
\hline & Mean & SD & Mean & SD & Mean & SD & Mean & SD \\
\hline BMR (MJ/d) & $7 \cdot 13$ & 0.82 & $7 \cdot 13$ & 0.97 & $5 \cdot 82$ & 0.83 & $5 \cdot 71$ & 0.61 \\
\hline TEE (MJ/d) & $13 \cdot 13$ & $2 \cdot 12$ & $12 \cdot 20$ & $2 \cdot 01$ & 11.04 & $2 \cdot 60$ & $9 \cdot 31^{*}$ & 1.27 \\
\hline PAL & 1.84 & 0.22 & 1.71 & 0.21 & 1.88 & 0.26 & $1.63^{\star *}$ & 0.19 \\
\hline Level of work $\ddagger$ & \multicolumn{2}{|c|}{$\mathrm{M}-\mathrm{H}$} & \multicolumn{2}{|c|}{ M } & \multicolumn{2}{|c|}{$\mathrm{H}$} & \multicolumn{2}{|c|}{$\mathrm{M}$} \\
\hline
\end{tabular}

Mean values were significantly different from those of rural women: ${ }^{\star} P<0.05,{ }^{\star \star} P<0.01$.

† For details of subjects and procedures, see Table 1 and p. 66.

‡ Level of work classified according to PAL into light, moderate $(\mathrm{M})$ and heavy $(\mathrm{H})$ categories (World Health Organization/Food and Agriculture Organization/United Nations University, 1985).

either sex. In men there were no significant differences in TEE or PAL. In contrast, significant differences were found in these indices in women (TEE, $P<0.05$, PAL, $P<0.01)$. According to the work levels of WHO/FAO/ UNU (1985), PAL were moderate to heavy for rural men, moderate for urban men and women, and heavy for rural women. These results suggested that urban men and women were less active than their rural counterparts, although not significantly so for men.

Using flex-HR as the cut-off point, the recorded data (1440 min) were divided into three categories: sleeping, sedentary $(\mathrm{HR} \leq$ flex $)$ and active $(\mathrm{HR}>$ flex $)$. The active category was further subdivided into 'moderately-active' (flex $<\mathrm{HR} \leq 1.2 \times$ flex) and 'highly-active' $(\mathrm{HR}>1.2 \times$ flex) (Table 3 ). The cut-off points (i.e. $1 \cdot 2 \times$ flex) were determined by considering that the mean HR of lying down (the lowest intensity among the observed activities) was about $80 \%$ flex-HR and the same rate $(20 \%)$ below or above the flex-HR point (i.e. 0.8 or $1.2 \times$ flex). There were considerable differences between rural subjects and urban subjects, and both men and women had a similar tendency in the pattern of their time allocation when rural subjects and urban subjects were compared. Data analysis showed that sedentary time was longer (men, $P<0.05$, women,

Table 3. Time $(\mathrm{min} / \mathrm{d})$ spent in the different categories of physical activity by men and women from rural and urban populations of Papua New Guinea†

(Mean values and standard deviations)

\begin{tabular}{|c|c|c|c|c|c|c|c|c|}
\hline & \multicolumn{4}{|c|}{ Men } & \multicolumn{4}{|c|}{ Women } \\
\hline & \multicolumn{2}{|c|}{ Rural (n 15) } & \multicolumn{2}{|c|}{ Urban (n 14) } & \multicolumn{2}{|c|}{ Rural (n 12) } & \multicolumn{2}{|c|}{ Urban ( $n 15$} \\
\hline & Mean & SD & Mean & SD & Mean & SD & Mean & SD \\
\hline & & 69 & & & & 36 & 52 & 47 \\
\hline Sedenta & 623 & 129 & $741^{*}$ & 117 & 602 & 101 & $731^{\star *}$ & 71 \\
\hline Active & 281 & 95 & 227 & 94 & 315 & 112 & $189^{\star *}$ & 76 \\
\hline ACT-1 & 197 & 59 & 209 & 87 & 241 & 71 & $169^{*}$ & 64 \\
\hline ACT-2 & 85 & 46 & $18^{\star \star \star}$ & 15 & 74 & 57 & $20^{\star *}$ & 17 \\
\hline
\end{tabular}

ACT-1, moderately-active subdivision of active category (flex $<$ heart rate $\leq$ 1.2 times flex); ACT-2, highly-active subdivision of active category (heat rate $>1.2$ times flex)

Mean values were significantly different from those of rural subjects: ${ }^{*} P<$ $0.05,{ }^{\star \star} P<0.005,{ }^{\star \star \star} P<0.0001$.

† For details of subjects and procedures, see Table 1 and p. 66.
$P<0.005)$ and active time shorter among women $(P<$ $0 \cdot 005$ ) for urban subjects than for rural subjects. Urban men spent a shorter time sleeping (by $65 \mathrm{~min}, P<0.05$ ) than rural men, although the sleep time was identical in rural women and urban women.

PAL value was also divided into four categories, as described earlier, in order to compare the differences between rural and urban subjects (Fig. 1). Specifically:

$$
\begin{aligned}
\mathrm{PAL}= & \mathrm{TEE} / \mathrm{BMR}, \\
= & ((\Sigma \text { sleeping } \mathrm{EE})+(\Sigma \text { sedentary EE }) \\
& +(\Sigma \mathrm{ACT}-1 \mathrm{EE})+(\Sigma \mathrm{ACT}-2 \mathrm{EE})) / \mathrm{BMR}, \\
= & ((\Sigma \text { sleeping } \mathrm{EE} / \mathrm{BMR})+(\Sigma \text { sedentary EE } / \mathrm{BMR}) \\
& +(\Sigma \mathrm{ACT}-1 \mathrm{EE} / \mathrm{BMR}) \\
& +(\Sigma \mathrm{ACT}-2 \mathrm{EE} / \mathrm{BMR})), \\
= & \mathrm{PAL}_{\text {sle }}+\mathrm{PAL}_{\mathrm{sed}}+\mathrm{PAL}_{\mathrm{ACT}-1}+\mathrm{PAL}_{\mathrm{ACT}-2},
\end{aligned}
$$

where $\mathrm{PAL}_{\text {sle }}, \mathrm{PAL}_{\text {sed }}, \mathrm{PAL}_{\mathrm{ACT}-1}, \mathrm{PAL}_{\mathrm{ACT}-2}$ are the sleeping, sedentary, moderately-active and highly-active components respectively. As illustrated in Fig. 1, the active component of PAL (sum of PAL $\mathrm{PCT}_{\mathrm{A}-1}$ and $\mathrm{PAL}_{\mathrm{ACT}-2}$ ) was lower in urban women than in rural women $(P<0.05)$, while the sedentary component $\left(\mathrm{PAL}_{\mathrm{sed}}\right)$ was significantly higher in both urban men and women $(P<0.05)$.

Activity profiles $(24 \mathrm{~h})$ were compared for each $2 \mathrm{~h}$ period (00.01-02.00, 02.01-04.00, 04.01-06.00 hours, etc.), averaged minute-by-minute, to derive the physical exertion index, i.e. average HR value/flex-HR $\times 100$ (Yamauchi et al. 2000) for each $2 \mathrm{~h}$ period. This analysis was based on the presence of systematic and substantial gender differences in raw HR values. The average $24 \mathrm{~h}$ activity profiles for each sample are depicted in Fig. 2. Considerable differences between rural and urban subjects were found in the morning in both sexes. The physical exertion index values were relatively stable throughout the day at $<100$ in urban subjects, while they fluctuated throughout the day in rural subjects, showing peak values in the morning, although the levels in other periods were similar to those seen in urban subjects.

Dietary energy, protein and fat intakes and daily energy 


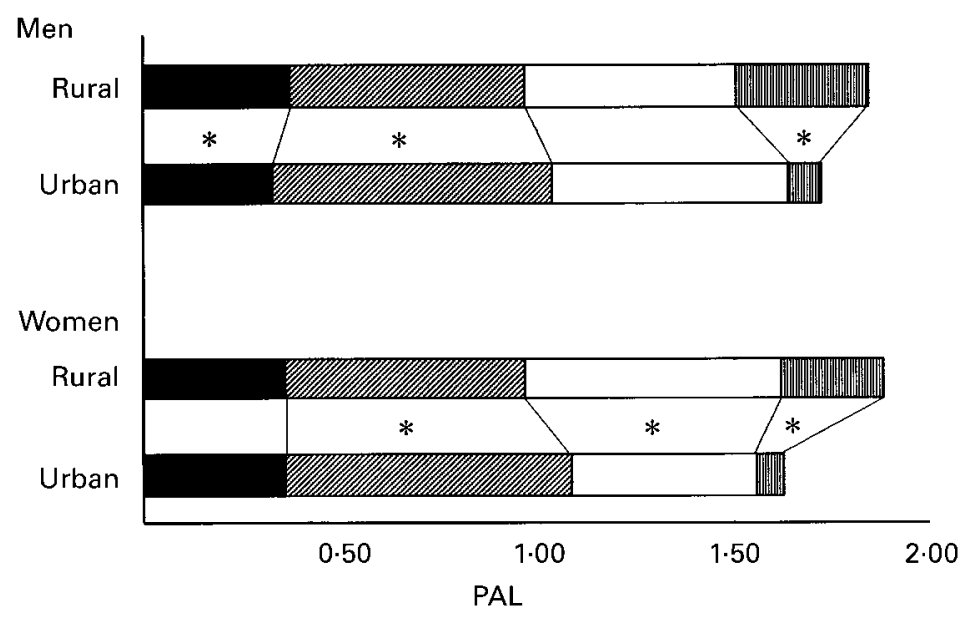

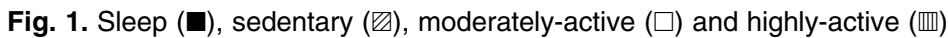
components of daily physical activity levels (total energy expenditure/BMR; $\mathrm{PAL}$ ) of men and women from rural and urban populations of Papua New Guinea ( $n$ 56). Mean values were significantly different between urban dwellers and rural villagers: ${ }^{*} P<0.05$. For details of subjects and procedures, see Table 1 and p. 66.

balance (total daily energy intake (TEI) - TEE) are shown in Table 4. Extra energy and protein are recommended for lactation (WHO/FAO/UNU, 1985). In fact, Norgan et al. (1974) have reported that the lactating women among PNG Highlanders (Lufa) had a significantly higher energy intake (by $0.75 \mathrm{MJ} / \mathrm{d}$ ) than the non-pregnant non-lactating women. In the present study, the values for energy and protein intake were adjusted for lactating women (four rural and six urban women) by reducing energy intakes by $2.1 \mathrm{MJ} / \mathrm{d}$ and protein intakes by $17.5 \mathrm{~g} / \mathrm{d}$ (for the first 6 months postpartum) or $13.0 \mathrm{~g} / \mathrm{d}$ (after 6 months postpartum) according to WHO/FAO/UNU (1985). The unadjusted energy and protein intakes were 11.20 (SD

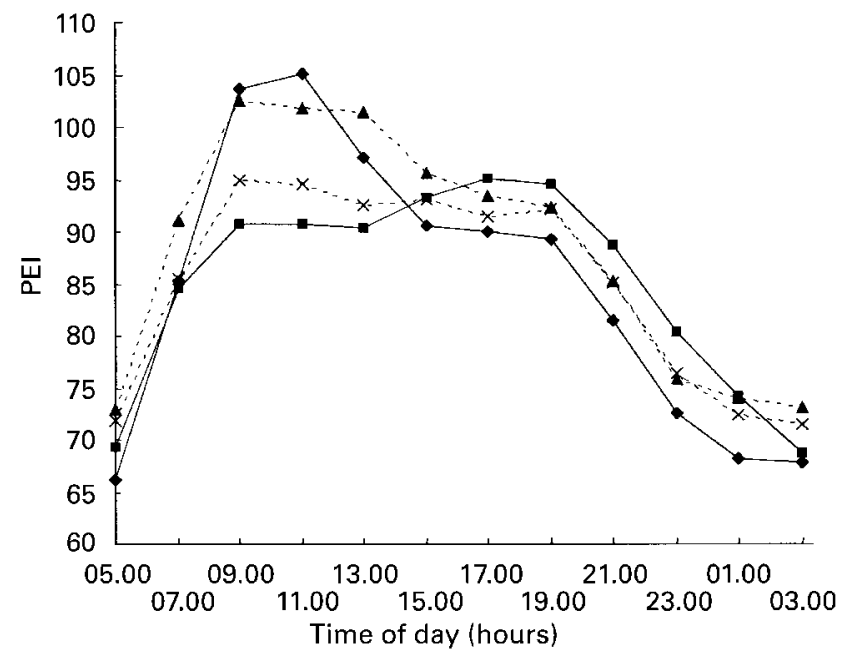

Fig. 2. Daily activity profiles of men and women from rural and urban populations of Papua New Guinea ( $n$ 56). Physical exertion index (average heart rate/flex-heart rate $\times 100 ; \mathrm{PEI}$ ) values were calculated for consecutive $2 \mathrm{~h}$ periods over $24 \mathrm{~h}$. $(\bullet)$, Rural men; $(\boldsymbol{\square})$, urban men; $(\boldsymbol{\Lambda})$, rural women; $(\times)$, urban women. For details of subjects and procedures, see Table 1 and p. 66.
$2 \cdot 83$ ) $\mathrm{MJ} / \mathrm{d}$ and 53 (SD 27) g/d respectively for rural women and 10.43 (SD 1.97) MJ/d and 71 (SD 23) g/d respectively for urban women. Since the percentage of lactating women was relatively low $(37, n 10)$ and adjusted values were levelled, the difference between adjusted and unadjusted values was small (6-8 \%) and considered negligible. Here we used the adjusted values for comparison between rural and urban subjects (Table 4). No significant differences were found in TEI and TEI/BMR between rural and urban subjects for both sexes. Protein and fat intakes were, on the other hand, higher in the urban samples for both sexes, although the protein intake for women was not significantly different between the two groups. The balance between TEI and TEE was $<7 \%$ in each group.

\section{Discussion}

Differences in body size between rural and urban subjects

Urban men and women in the present study were taller and heavier than their rural counterparts. However, no significant difference was found in BMI between the two groups because the increased body weight in urban subjects was offset by increased stature. According to another survey conducted by our laboratory using a large sample of rural villagers and urban migrants which included almost all subjects in this study (eighty-six rural men, 127 rural women, 101 urban men and thirty-nine urban women), the mean values for body weight, height and BMI were almost identical to those of the present study, although the differences between rural and urban subjects were more marked (Table 5). Table 5 shows the data of two anthropometric surveys conducted for the same Hulispeaking group. The first was conducted in August 1995 as a part of a large study on cardiovascular risk factors of migrants in Port Moresby (Natsuhara et al. 2000). In that study almost all adult Huli migrants who resided in five settlements in Port Moresby were invited to participate. 
Table 4. Dietary energy, protein and fat intakes and daily energy balance in men and women from rural and urban populations in Papua New Guineat

(Mean values and standard deviations)

\begin{tabular}{|c|c|c|c|c|c|c|c|c|}
\hline & \multicolumn{4}{|c|}{ Men } & \multicolumn{4}{|c|}{ Women } \\
\hline & \multicolumn{2}{|c|}{ Rural (n 15) } & \multicolumn{2}{|c|}{ Urban (n 14) } & \multicolumn{2}{|c|}{ Rural (n 12) } & \multicolumn{2}{|c|}{ Urban (n 15) } \\
\hline & Mean & SD & Mean & SD & Mean & SD & Mean & SD \\
\hline TEI $(M J / d) \ddagger$ & $12 \cdot 23$ & 4.20 & 11.65 & $2 \cdot 75$ & $10 \cdot 53$ & 2.35 & $9 \cdot 62$ & $2 \cdot 65$ \\
\hline TEE (MJ/d) & $13 \cdot 13$ & $2 \cdot 12$ & $12 \cdot 20$ & $2 \cdot 01$ & 11.04 & $2 \cdot 60$ & $9 \cdot 31^{*}$ & 1.27 \\
\hline Balance§ & -0.97 & 3.63 & -0.57 & $2 \cdot 36$ & -0.54 & $2 \cdot 74$ & 0.29 & 2.56 \\
\hline TEI/BMR & 1.69 & 0.51 & 1.64 & 0.34 & 1.82 & 0.36 & 1.67 & 0.36 \\
\hline Protein intake $(\mathrm{g} / \mathrm{d}) \ddagger$ & 49 & 30 & $73^{\star}$ & 21 & 48 & 23 & 65 & 28 \\
\hline Fat intake $(\mathrm{g} / \mathrm{d})$ & 18 & 21 & $82^{* *}$ & 48 & 23 & 24 & $84^{\star \star \star}$ & 36 \\
\hline
\end{tabular}

TEI, total energy intake; TEE, total energy expenditure.

Mean values were significantly different from those of rural villagers: ${ }^{\star} P<0.05$, ${ }^{\star \star} P<0.0005,{ }^{\star \star \star} P<0.0001$

† For details of subjects and procedures, see Table 1 and p. 66.

$\ddagger$ Adjusted for lactating women ( $n$ 10).

$\S$ Energy balance $=$ TEI - TEE.

The second study was conducted in July and August 1998 with rural adults in Tari basin, including the two villages of the present study. Thus, the lack of significant difference in body weight and BMI for men and in stature and BMI for women in the present study is probably due to the small sample size. Furthermore, the finding that urban subjects who were born and raised until pubescence or adolescence in their home villages had a significantly larger body size, especially in height, suggests that well-nourished individuals had selectively migrated to the capital city (Port Moresby). It is possible, however, that a long adolescent growth spurt also contributed to the difference between the height of urban and rural groups (Heywood \& Norgan, 1982; Norgan, 1995).

\section{Reduced daily physical activity level in urban subjects}

PAL of the subjects participating in the present study were comparable with those described by Ferro-Luzzi \& Martino (1996) who reviewed fifty-five studies of about 1550 subjects in free-living conditions in more than twenty developed and developing countries. According to their study the PAL values of Third World subjects were 1.84 (SD 0.31) for male subjects and 1.65 (SD 0.17) for female subjects whereas those of Western subjects were 1.74 (SD 0.15 ) for male subjects and 1.64 (SD 0.18) for female subjects. Compared with Third World subjects, PAL values for rural Huli villagers were similar for men and higher for women, reflecting the gender inequality in labour commonly observed in PNG Highlands (Waddell, 1972; Strathern, 1982; Allen et al. 1995). This factor has been discussed in detail in our recent report (Yamauchi et al. 2000). For the Huli urban subjects, on the other hand, PAL values were lower than those of Third World subjects, and even Western subjects. According to the review of FerroLuzzi \& Martino (1996) on Third World populations, including both subsistence and urban populations, the highest two or three PAL values for male or female subjects in urban Third World populations were similar to or lower than those of the urban migrants in the present study (for men; Philippines drivers 1.64, Philippines textile mill workers 1.64; for women: Guatemala urban resettled of lower socio-economic status $1 \cdot 58$, Philippine typists $1 \cdot 60$, Philippine housewives 1.57). Thus, the lower PAL values of the Huli urban migrants are considered to reflect a general tendency that urban dwellers in developing countries are less active than those in developed countries.

What are the mechanisms of low PAL observed in urban subjects? Several studies have shown a close relationship between PAL and the percentage of time spent above the flex-HR point (Livingstone et al. 1990; Leonard et al. 1995; Murayama \& Ohtsuka, 1999). In the present study

Table 5. Body weight, height and BMI of rural and urban men and women from a larger study population in Papua New Guinea, including subjects from the present study $†$

(Mean values and standard deviations)

\begin{tabular}{|c|c|c|c|c|c|c|c|c|}
\hline & \multicolumn{4}{|c|}{ Men } & \multicolumn{4}{|c|}{ Women } \\
\hline & \multicolumn{2}{|c|}{ Rural¥ (n 86) } & \multicolumn{2}{|c|}{ Urban§ (n 101) } & \multicolumn{2}{|c|}{ Ruralł (n 127) } & \multicolumn{2}{|c|}{ Urban§ (n 39) } \\
\hline & Mean & SD & Mean & SD & Mean & SD & Mean & SD \\
\hline Weight (kg) & $59 \cdot 8$ & 9.5 & $65 \cdot 5^{\star \star \star}$ & 7.2 & $50 \cdot 8$ & $7 \cdot 1$ & $62 \cdot 1^{\star \star \star}$ & 11.3 \\
\hline Height (m) & 1.58 & 0.07 & $1.62^{* * *}$ & 0.05 & 1.50 & 0.05 & $1.52^{*}$ & 0.05 \\
\hline BMI $\left(\mathrm{kg} / \mathrm{m}^{2}\right)$ & $24 \cdot 0$ & $2 \cdot 8$ & $25 \cdot 0^{* \star}$ & $2 \cdot 4$ & 22.7 & 2.5 & $27 \cdot 0^{\star \star \star}$ & 4.5 \\
\hline
\end{tabular}

Mean values were significantly different from those of rural villagers: ${ }^{\star} P<0.05,{ }^{\star \star} P<0.01,{ }^{\star \star \star} P<0.001$.

† For details of subjects and procedures, see Table 1 and p. 66.

$\ddagger$ Surveyed in 1998.

$\S$ Surveyed in 1995 (Natsuhara et al. 2000). 


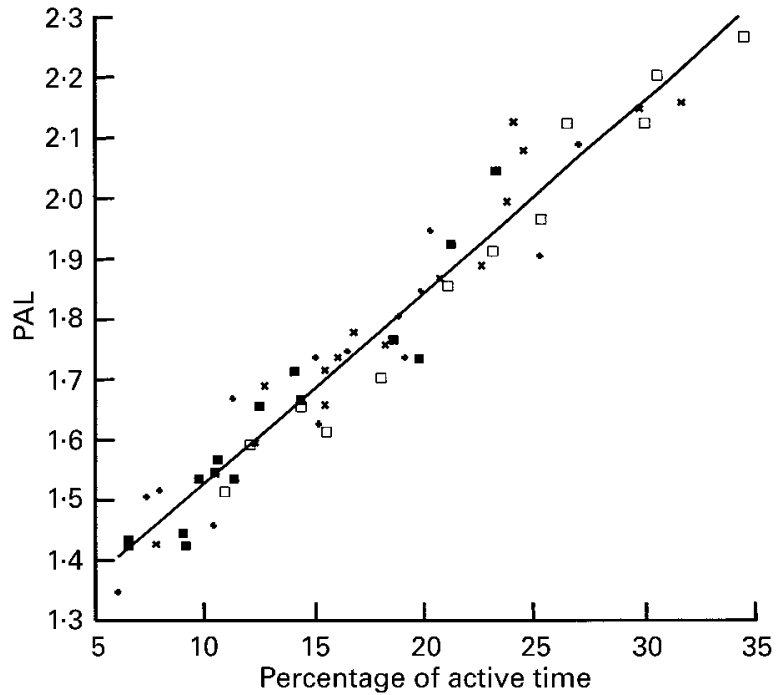

Fig. 3. Correlation between daily physical activity level (total energy expenditure/BMR; PAL) and percentage of time spent being active (average heart rate $>$ flex) for men and women from rural and urban populations of Papua New Guinea $(n 56)$. Rural men $(\times)$ urban men $(+)$, rural women $(\square)$, urban women $(\boldsymbol{\square})$. PAL $=0.032(\%)+1.212, r$ 0.97 . For details of subjects and procedures, see Table 1 and p. 66 .

there was a significant positive correlation ( $r$ 0.97, $P<$ $0.0001)$ between PAL and the percentage of active time (HR > flex; Fig. 3). In fact, in urban subjects who had lower PAL than rural subjects active time decreased and sedentary time $(\mathrm{HR} \leq$ flex) increased (Table 3$)$; consequently, the active component of PAL was reduced and sedentary component of PAL was increased in urban subjects (Fig. 1). It was clear that the low active component of PAL in urban dwellers, due to a reduced active time, was the main factor in reducing the EE as a whole. This phenomenon is considered as the most typical effect of urbanisation from the energy viewpoint. Furthermore, in view of the progressive change in the intensity of physical activity in each sample throughout the day, considerable differences between rural and urban subjects were found in the morning in both sexes (Fig. 2). The high levels of physical activity recorded in the morning in rural subjects reflected intensified agricultural activities, especially in women $(P<0 \cdot 01$; Table 2$)$.

\section{Energy balance and methodological assessments}

Rural subjects consumed low-protein low-fat meals containing mainly sweet potatoes and local greens. In contrast, urban subjects depended totally on purchased food such as rice, tinned fish and chicken, leading to increased intakes of protein and fat (Table 4). Ulijaszek (1992, 1995) reviewed the mean energy intake and $\mathrm{EE}$ in non-industrialised populations. In six of twelve samples the reported energy intake was more than $1 \mathrm{MJ}$ below $\mathrm{EE}$, a difference that cannot be explained by possible seasonal fluctuations in work output and food availability. In the present study, a negative energy balance was noted in three of the four groups (Table 4). Although a large negative energy balance such as that described earlier $(>1 \mathrm{MJ} / \mathrm{d})$ was not found in any group, it is possible that we have underestimated the energy intake in the present study. Under-reporting of energy intake was not likely because subjects were under observation during the daytime and all food was measured just before it was consumed. Admittedly, the observer effect cannot be completely excluded, i.e. subjects might eat less on the day of investigation because they are under constant observation. However, TEI and protein and fat intakes for rural subjects in the present study were similar to or even higher than those for twenty-eight households of a Huli-speaking sample studied using a consecutive $6 \mathrm{~d}$ food weighing survey (daily per capita intakes: $11.0 \mathrm{MJ} / \mathrm{d}$, $39.3 \mathrm{~g}$ protein/d, 13.1 g fat/d; Kuchikura, 1999). Thus, we believe that the small negative energy balance observed in the present study was not influenced by an observer effect, the small sample size or the short observation period.

In fact, TEE might have been overestimated due to overestimation of EE during the step test. In the present study, EE values during step tests were not obtained from the study subjects but were estimated using gender-andweight-specific equations for similar samples of Hulispeaking people (Yamauchi \& Ohtsuka, 2000). In that study, the net mechanical efficiency values for three levels of the step tests were compared with those for worldwide populations reported in previous studies (Katzmarzyk et al. 1996). Net mechanical efficiencies of the Huli-speaking population (16 and $15 \%$ for rural men and women respectively, and $17 \%$ for both urban men and women) were comparable with those of previous studies and WHO standards (i.e. 16 \%; Shephard, 1967; Shephard et al. 1968; Anderson et al. 1971). Thus, we conclude that the EE of the step tests, and consequently TEE for present participants, are unlikely to be overestimated.

A further explanation of the small negative energy balance in rural subjects may be due to the fact that rural subjects from two villages (Heli and Wenani) suffered from an extended rain season during the study period, and the food intake or energy intake of Heli villagers was unusually low. This issue was discussed in detail in our previous report (Umezaki et al. 1999). In fact, we found significant differences in energy intake between the subsamples in both rural men and women $(9.72$ and $15.04 \mathrm{MJ} / \mathrm{d}$ in Heli and Wenani men respectively, $P<0.01 ; 8.79$ and $12.22 \mathrm{MJ} / \mathrm{d}$ in Heli and Wenani women respectively, $P<0.005)$.

The results of the food and nutrient intake survey demonstrated a well-maintained daily energy balance, especially in urban subjects. However, low TEI and TEE, which were observed in urban subjects, are considered to be risk factors for obesity and cardiovascular disorders (King \& Collins, 1989; Dowse et al. 1994; Hodge et al. 1995). For instance, Ferro-Luzzi \& Martino (1996) suggested that a PAL of 1.8 was the threshold for triggering such diseases. Fat intake in urban subjects, which was markedly higher than that of rural subjects, was comparable with that in subjects from a PNG coastal population (Wanigela) who migrated to a settlement in Port Moresby (men $71 \mathrm{~g} / \mathrm{d}$, women $65 \mathrm{~g} / \mathrm{d}$ ), and the fat consumed was reported to be predominantly saturated fat (Hodge et al. 1996). Taking into consideration that more than $60 \%$ of the fat intake of 
Huli migrants in Port Moresby was provided by sheep meat, butter and chicken, the fat intake pattern appears to be almost identical to that of Wanigela migrants. These findings imply that the level of $\mathrm{EE}$ of urban dwellers (whose energy intake was balanced), together with higher intake of saturated fat, tended to increase the risks of degenerative disorders following migration to, and settlement in, an urban environment.

In conclusion, lifestyle changes in urban migrants were examined in the present study by comparing their food intake and EE data with those of their rural counterparts. The effects of urbanisation on daily physical activity were evident in the considerably lower PAL in urban subjects than in rural subjects, especially in women. Large increases in protein and fat intakes were noted in urban subjects due to dietary changes from local to purchased foods. The reduction in PAL among urban dwellers, perhaps together with increased fat intake, is considered to increase the risks of obesity and chronic degenerative diseases.

\section{Acknowledgements}

We thank Dr John Veil and Dr Deborah Lehmann for selecting the subject communities. We also thank the staff of Papua New Guinea Institute of Medical Research at Tari and the staff of the National Research Institute of Papua New Guinea for support of our fieldwork. Finally, we are grateful to the Huli people in the Tari basin and Port Moresby for their participation in the study. This research was supported by grants from the Japanese Ministry of Education, Science and Culture.

\section{References}

Allen BJ, Bourke RM \& Hide RL (1995) The sustainability of Papua New Guinea agricultural systems: the conceptual background. Global Environmental Change 5, 297-312.

Anderson KL, Shephard RJ, Denolin H, Varnauskas E \& Masironi R (1971) Fundamentals of Exercise Testing. Geneva: WHO.

Ceesay SM, Prentice AM, Day KC, Murgatroyd PR, Goldberg GR, Scott W \& Spurr GB (1989) The use of heart rate monitoring in the estimation of energy expenditure: a validation study using indirect whole-body calorimetry. British Journal of Nutrition 61, 175-186.

Douglas CG (1911) A method for determining the total respiratory exchange in man. Journal of Physiology 42, xvii-xviii.

Dowse GK, Spark RA, Mavo B, Hodge AM, Erasmus RT, Gwalimu M, Knight LT, Koki G \& Zimmet PZ (1994) Extraordinary prevalence of non-insulin-dependent diabetes mellitus and bimodal plasma glucose distribution in the Wanigela people of Papua New Guinea. Medical Journal of Australia 160, 767-774.

Durnin JVGA (1990) Low energy expenditure in free-living populations. European Journal of Clinical Nutrition 44, 95102.

Ferro-Luzzi A \& Martino L (1996) Obesity and physical activity. In The Origins and Consequences of Obesity. Ciba Foundation Symposium no 201, pp. 207-227 [DJ Chadwick and G Cardew, editors]. Chichester, West Sussex: J. Wiley.

Goldberg GR, Prentice AM, Davies HL \& Murgatroyd PR (1988) Overnight and basal metabolic rates in men and women. European Journal of Clinical Nutrition 42, 137-144.
Heywood PF \& Norgan NG (1982) Human growth in Papua New Guinea. In Human Biology in Papua New Guinea. The Small Cosmos, pp. 234-248 [RD Attenborough and MP Alpers, editors]. Oxford: Oxford University Press.

Hodge AM, Dowse G, Koki G, Mavo B, Alpers MP \& Zimmet PZ (1995) Modernity and obesity in coastal and highland Papua New Guinea. International Journal of Obesity 19, 154-161.

Hodge AM, Montgomery J, Dowse GK, Mavo B, Watt T, Alpers MP \& Zimmet PZ (1996) Diet in an urban Papua New Guinea population with high levels of cardiovascular risk factors. Ecology of Food and Nutrition 35, 311-324.

Hongo T \& Ohtsuka R (1993) Nutrient compositions of Papua New Guinea Foods. Man and Culture in Oceania 9, 103-125.

James WPT, Ferro-Luzzi A \& Waterlow JC (1988) Definition of chronic energy deficiency in adults. European Journal of Clinical Nutrition 42, 969-981.

Katzmarzyk PT, Leonard WR, Crawford MH \& Shkernik RI (1994) Resting metabolic rate and daily energy expenditure among two indigenous Siberian populations. American Journal of Human Biology 6, 719-730.

Katzmarzyk PT, Leonard WR, Stephen MA, Berti PR \& Ross AGP (1996) Differences between observed and predicted energy costs at rest and during exercise in three subsistence-level populations. American Journal of Physical Anthropology 99, 537-545.

King H \& Collins AM (1989) A modernity score for individuals in Melanesian Society. Papua New Guinea Medical Journal 32, $11-22$.

Kuchikura Y (1999) The cost of diet in a Huli community of Papua New Guinea: a linear programming analysis of subsistence and cash-earning strategies. Man and Culture in Oceania 15, 65-90.

Leonard WR, Katzmarzyk PT, Stephen MA \& Ross AGP (1995) Comparison of the heart rate-monitoring and factorial methods: assessment of energy expenditure in highland and coastal Ecuadorians. American Journal of Clinical Nutrition 61, 11461152.

Livingstone MBE, Prentice AM, Coward WA, Ceesay SM, Strain JJ, McKenna PG, Mewin GB, Baker ME \& Hickey RJ (1990) Simultaneous measurement of free-living energy expenditure by the doubly labelled water $\left({ }^{2} \mathrm{H}_{2}{ }^{18} \mathrm{O}\right)$ method and heart-rate monitoring. American Journal of Clinical Nutrition 52, 59-65.

Murayama N \& Ohtsuka R (1999) Heart rate indicators for assessing physical activity level in the field. American Journal of Human Biology 11, 647-657.

Natsuhara K, Inaoka T, Umezaki M, Yamauchi T, Hongo T, Nagano M \& Ohtsuka R (2000) Cardiovascular risk factors of migrants in Port Moresby from the Highlands and island villages. Papua New Guinea. American Journal of Human Biology 12, 655-664.

Norgan NG (1995) Changes in patterns of growth and nutritional anthropometry in two rural modernizing Papua New Guinea communities. Annals of Human Biology 22, 491-513.

Norgan NG, Ferro-Luzzi A \& Durnin JVGA (1974) The energy and nutrient intake and the energy expenditure of 204 New Guinean adults. Philosophical Transactions of the Royal Society of London 268B, 309-348.

Panter-Brick C, Todd A, Baker R \& Worthman C (1996) Comparative study of flex heart rate in three samples of Nepali boys. American Journal of Human Biology 8, 653-660.

Shephard RJ (1967) The prediction of 'maximal' oxygen consumption using a new progressive step test. Ergonomics 10, $1-15$.

Shephard RJ, Allen C, Benade AJS, Davies CTM, di Prampero PE, Hedman R, Merriman JE, Myhre K \& Simmons R (1968) 
Standardization of submaximal exercise tests. Bulletin of the World Health Organization 38, 765-775.

Sinnett PF, Kevau H \& Tyson D (1992) Social change and the emergence of degenerative cardiovascular disease in Papua New Guinea. In Human Biology in Papua New Guinea. The Small Cosmos, pp. 373-386 [RD Attenborough and MP Alpers, editors]. Oxford: Oxford University Press.

Spurr GB, Dufour DL \& Reina JC (1996) Energy expenditure of urban Colombian women: a comparison of patterns and total daily expenditure by the heart rate and factorial methods. American Journal of Clinical Nutrition 63, 870-878.

Spurr GB, Prentice AM, Murgatroyd PR, Goldberg GR, Reina JC \& Christman NT (1988) Energy expenditure from minute-byminute heart-rate recording: comparison with indirect calorimetry. American Journal of Clinical Nutrition 48, 552-559.

Stein TP, Johnston FE \& Greiner L (1988) Energy expenditure and socioeconomic status in Guatemala as measured by the doubly labelled water method. American Journal of Clinical Nutrition 47, 196-200.

Strathern A (1982) Inequality in Highlands Societies. Cambridge: Cambridge University Press.

Taylor R, Badcock J, King H, Pargeter K, Zimmet P, Fred T, Lund M, Ringrose H, Bach F, Wang RL \& Sladden T (1992) Dietary intake, exercise, obesity and non-communicable disease in rural and urban populations of three Pacific Island Countries. Journal of the American College of Nutrition 11, 283-293.

Ulijaszek SJ (1992) Human energetics methods in biological anthropology. Yearbook of Physical Anthropology 35, 215242.

Ulijaszek SJ (1995) Human Energetics in Biological Anthropology. Cambridge: Cambridge University Press.

Umezaki M, Yamauchi T \& Ohtsuka R (1999) Diet among the Huli in Papua New Guinea Highlands when they were influenced by the extended rainy period. Ecology of Food and Nutrition 37, 409-427.

Waddell E (1972) The Mound Builders: Agricultural Practices, Environment, and Society in the Central Highlands of New Guinea. Seattle, WA: Washington University Press.

Yamauchi T \& Ohtsuka R (2000) Basal metabolic rate and energy costs at rest and during exercise in rural- and urban-dwelling Papua New Guinea Highlanders. European Journal of Clinical Nutrition 54, 494-499.

Yamauchi T, Umezaki M \& Ohtsuka R (2000) Energy expenditure, physical exertion and time allocation among Huli-speaking people in the Papua New Guinea Highlands. Annals of Human Biology (in the Press).

World Health Organization/Food and Agriculture Organization/ United Nations University (1985) Energy and Protein Requirements. Technical Report Series no 724. Geneva: WHO. 